\title{
FUZZY SIMPLE ADDITIVE WEIGHTING BASED, DECISION SUPPORT SYSTEM APPLICATION FOR ALTERNATIVE CONFUSION REDUCTION STRATEGY IN SMARTPHONE PURCHASES
}

\author{
${ }^{1}$ Robertus Nugroho Perwiro Atmojo, ${ }^{1}$ Anindito, ${ }^{2}$ Bens Pardamean, \\ ${ }^{2}$ Bahtiar Saleh Abbas, ${ }^{3}$ Anggita Dian Cahyani and ${ }^{4}$ Imanuel Didimus Manulang \\ ${ }^{1}$ School of Information Systems, Bina Nusantara University, West Jakarta, Indonesia \\ ${ }^{2}$ Graduate School of Information Systems, Bina Nusantara University, West Jakarta, Indonesia \\ ${ }^{3}$ Department of Psychology, Bina Nusantara University, West Jakarta, Indonesia \\ ${ }^{4}$ Research and Technology Transfer Office, Bina Nusantara University, West Jakarta, Indonesia
}

Received 2014-01-02; Revised 2014-01-04; Accepted 2014-02-08

\begin{abstract}
Consumer confusion is a phenomena when the consumer experiencing several confusion problems when she/he should to purchase products/services. Usually, consumer will do a strategy to coping the confusion, that strategy is known as Confusion Reduction Strategy. The conventional ways usually taken by the consumer to reduce the confusion are, such as: Asking for product recommendation to close relatives, seeking for an additional product information on the internet and so on. However, suggestions and recommendations from conventional sources obtained by the consumer, sometimes are not always accurate (not objective) and time consuming (inefficient). Therefore, this research proposes a Decision Support System (DSS) application to cope with the confusion. In this study, the comparison results between conventional methods (such as: Asking advice to close relatives or seeking for an additional information on the internet) with the proposed method (the DSS) were presented. In addition, another implication of this study is to get the factors that causing consumer confusion in case of smartphone purchases. This research used mixed-method approach, implemented through interview and survey. Research samples were 136 potential smartphone buyers which are converted to 27 smartphone buyers; brand image is the main source of consumer confusion (mean 3.98, std. dev 0.86), followed by proliferation of brands, services and models of smartphone products (mean 3.89, std. dev 0.82). Respondents often use Word of Mouth (WoM) communication as main source of information to reduce the confusion, results of 16 from 27 transactions were contributed from WoM. DSS application contributed only 2 of 27 smartphone transactions. Further research for the development of mobile based DSS application as an alternative conventional CRS needs to be conducted, because of the potential success of static desktop based DSS application in reducing potential consumer confusion especially for value oriented buyers.
\end{abstract}

Keywords: Consumer Confusion, Decision Support System, Simple Additive Weighting, Fuzzy Logic, Confusion Reduction Strategy

\section{INTRODUCTION}

Feelings of regret, dissatisfaction and disappointment after buying a product/service are often perceived by consumers. Those feelings can be caused by wrong choice of the product, having no enough time to do the purchase consideration, fault Corresponding Author: Robertus Nugroho Perwiro Atmojo, School of Information Systems, Bina Nusantara University, West Jakarta, Indonesia 
confusion or confusing feeling as consumer confusion (Mitchell and Papavassiliou, 1999; Mitchell et al., 2005; Schweizer et al., 2006; Kasper et al., 2010). If the level of confusion reaches its peak, consumers will instinctively have strategies to reduce the impact of confusion. Experts called these strategies as Confusion Reduction Strategies (CRS). The conventional CRS method, such as buying cancellation and consulting with close relatives for product recommendations, is the most common strategy that consumers do to reduce confusion. Several consumer confusion studies led by (Leek and Chansawatkit, 2006; Leek and Kun, 2006; Casini et al., 2008) confirmed that the conventional CRS method is the most simple and the most convenience way as buying references. However, the conventional CRS method does not always produce accurate (objective) and efficient product alternative recommendations. The consumer may fail to address the main purpose of buying something (Mitchell and Papavasilliou, 1997). This study proposed Decision Support Systems (DSS) model as an alternative of the conventional CRS method. Desktop based DSS application using Fuzzy Simple Additive Weighting (SAW) algorithm has brought to this study to help consumers choose the product independently; and smartphone product was used to be the research subject in this study. Why smartphone? Several reasons to brought smartphone as an interesting research subject are because of its brand proliferation in Indonesia market, the features and technologies offered, price according to its performance/functionality or may price relates to its brand that may lead consumers to face confusion. The research questions of this study are: (1) how is the effect of implementation of DSS application on smartphone sales? (2) what is the main source of consumer confusion in the smartphone purchases in Indonesia market? (3) what is the popular CRS-way choosen by customers to reduce his/her confusions?

\subsection{Related Works}

In simple words, consumer confusion is described as a situation where a consumer faces confused feeling when he/she wants to buy something. i.e., The confusing feeling may come when consumer wants to buy a personal computer (Leek and Kun, 2006); wants to buy a mobile phone (Leek and Chansawatkit, 2006); a wristwatch (Mitchell and Papavasilliou, 1997); a bottle of wine (Casini et al., 2008); or a motorcycle used to deliver children to go to school (Setiawan et al., 2012). Experts from the previous studies conclude the causes of consumer confusion, such as: (Table 1).

Mitchell and Papavassiliou (1999) stated CRS as a mechanism used by the consumer to reduce consumer confusion, the CRS actions could be: (1) doing nothing: To reduce the confusion, consumers do not do anything, the consumer does not care to think about buying a product and acts as if nothing ever plan to buy a product; (2) postpone/abandon the purchase: Consumers may postpone/abandon to buy a product caused by many factors, such as: Did not have enough money to purchase something; (3) share/delegate: Consumers follow the advice or suggestion from their close relatives like family, friend, or neighbor to purchase product as same as their relatives purchase; (4) clarify the buying goals: "Is this USD $\$ 800$ brand new smartphone worth with its features?"; (5) seeking additional information: "Mr. Didimus browsed consumers review in GSMarena.com to doubly check the processor performance of Samsung Galaxy S4 as promised as in television"; (6) narrow down the set of alternatives: "The 2012 best selling CDMA's smartphone in Indonesia is BlackBerry 9330, so $\mathrm{i}$ consider to purchase it as my daily use gadget because others do the same". Table 2 represents several CRS actions in various cultures in Asia and Europe.

Some characteristics of CRS like narrowing down several set of alternatives of product met with the vigorous use of DSS especially in Multi Criteria Decision Making (MCDM). Nowduri (2011) states the main use of DSS is for helping analysts to split a complex alternatives into several valuable decisions. As a subset of management information systems, the role of DSS applications in profit or non-profit organizations are very helpful to simplify the process of day to day operations, such as: Designing network topologies, solving group decision making problem, human capital management, stock inventories and many more (Eom, 2001). Adapting and modifying the conceptual framework of Consumer Confusion (CS) and its CRS by Leek and Chansawatkit (2006), this study proposed DSS application model as an another CRS alternatives that can be seen in Fig. 1. 


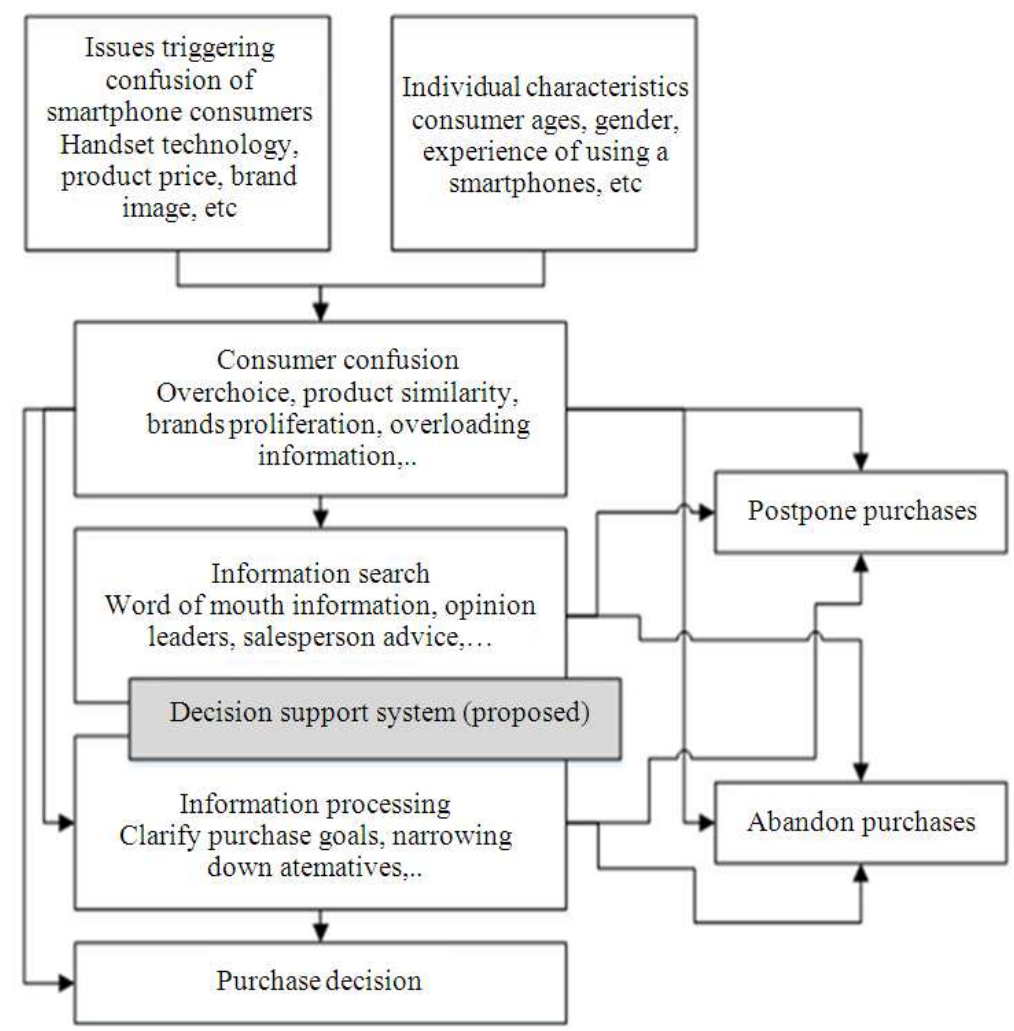

Fig. 1. The injection of DSS to the previous Leek and Chansawatkit (2006) CS-CRS conceptual model

Table 1. The main sources of consumer confusion

Previous studies

Leek and Kun (2006)

Mitchell et al. (2005)

Casini et al., (2008)

Leek and Chansawatkit (2006)
Consumer confusion problems

(1) overchoices product, (2) product similarities, (3) lacks of product information;

(4) product complexities, (5) untransparent price labelings, (6) lacks of user manual,

(7) overloading of information's

(8) proliferation of labels (product brands);

(9) misleading product information from salesperson and

(10) too much suggestions from relatives.

Table 2. CRS actions in various cultures

Previous studies

The most popular confusion reduction strategies used by consumers to reduce the confusion

Leek and Kun (2006)

The most frequent source of information used by Chinese people to purchase a personal computer product is Word of Mouth (WOM) information. They asking for suggestions to their close relatives before choosing the fit ones.

Leek and Chansawatkit (2006) As same as Chinese people, Thailand's in Bangkok metropolitan area used WOM information as an effective way to choose the mobile phone. When deciding to purchase a motorcycle,

Setiawan et al. (2012)

Semarang's (Indonesia) people seeking what is the motorcycle that their neighbors are use too? Refers to Mitchell and Papavassiliou (1999) the CRS actions taken by Semarang's people can be categorized as narrowing down the set of alternatives

Kasper et al. (2010) Overloading of information and overchoices products is the most popular problems when Dutch people are going to mobile phone market. The Dutch tends to seeking the most popular mobile phone brand or seeking for its prices when consider to purchase a mobile phone. Refers to Mitchell and Papavassiliou (1999) the CRS actions taken by Dutch people can be categorized as narrowing down the set of alternatives. 


\section{MATERIALS AND METHODS}

Mixed Method Research was adapted in this study because the data were analyzed both qualitatively and quantitatively (Creswell, 2009; Fidel, 2008). Fidel (2008) defines qualitative methods as a method of generating text/words, graphs, drawings while quantitative methods producing numbers as its product. Sampling techniques using survey research methodology approach as in (Leek and Kun, 2006; Case and King, 2008; Lugtig et al., 2011; Eret and Gokmenoglu, 2010) were used to answer the research questions.

\subsection{Study Design}

There were nine steps in this study to gather several information's about consumer confusion follows with its CRS. The nine steps show in Fig. 2.

\subsection{The Explanation of Fig. 2}

(a) START; (b) original source of information: Assumming every potential consumer which come to the smartphone's stall have a source information as used as buying references; (c) DSS injection: The DSS apps offered to every potential consumer which want to buy a smartphone product as an another CRS alternatives; (d) purchase decision: "Are there any smartphone purchases transactions which happened?"; (e) NO: Why potential consumer did not do the smartphone purchasing? Whether the potential consumer abandon the smartphone purchasing or postpone it and deciding to do the purchasing in the future? Short interview and information recording using a questionnaire instrument was done during this process. (f) YES: If smartphone purchases transaction happened, the next steps are checking about the purchase decision done by the potential consumer. Whether the DSS apps has a role to assist the potential consumer when she/he decided to choose the smartphone product which they want to buy? Short interview and information recording using a questionnaire instrument was done during this process. (g) YES: If the recommendations from the DSS apps was used by the potential consumer as a buying references so, what is the main reason for potential consumer using DSS recommendations as a final decision to purchase a smartphone? Whether the DSS apps is another accurately CRS alternative? Short interview and information recording using a questionnaire instrument was done during this process; (h) NO: What is the source of information often used by the potential consumer as a buying references? Which one the CRS alternative are used? Short interview and information recording using a questionnaire instrument was done during this process; (i) END.

\subsection{Questionnaire Design}

The questionnaire was developed to obtain the main cause of consumer confusion in choosing a smartphone. Convenience sampling (accidental sampling) was used to obtain information's about (a) consumer perceptions of unclarity confusion, similarity confusion and overchoice confusion, (b) consumer perceptions of adequacy on information searching about the product, (c) consumer strategies to search information about the product, (d) consumer perceptions towards source of information's about smartphone products on the market, (e) the most often source of information used by the consumer as purchase references and (f) factors most used by the consumer as a selection criteria. The use of convenience sampling methods and questionnaire instruments was adapted from the previous studies by Leek and Chansawatkit (2006) and Leek and Kun (2006). The questionnaire instrument was modified and then translated into Bahasa Indonesia. The results of the questionnaire reliability test from 30 respondents in the pilot survey obtained Cronbach's $\alpha$ value of 0.88 . The questionnaire is qualified, because the Cronbach's $\alpha$ value is greater than 0.60 (Sarjono and Julianita, 2011) and there is no need of item reduction from the 21 questionnaire items. Because the Cronbach's $\alpha$ value does not exceed the value of 0.9 (Tavakol and Dennick, 2011). Meanwhile, the results of questionnaire validity test $\left(\mathrm{Df}_{\mathrm{n}-2}=28\right)$ can be seen in Table 3 .

\subsection{Fuzzy SAW Algorithm in Simulation}

The software design method used in this study refers to the linear sequential model by (Pressman, 1997) (Fig. 3).

The Analysis steps on this study consist of (1) the explanation of simply simulation process of Fuzzy SAW method and (2) the explanation about aspects of criteria weighting. The simulation process consists of several steps; the steps are.

\section{Step 1:}

Identification of fuzzy numbers in linguistic variable to specify weighting scale alternatives and weighting criteria. The use of fuzzy linguistic variable refers to Aghajani et al. (2012) method. The scale indicator starts from very low (Sangat Rendah) to very high (Sangat Tinggi), then the scale of fuzzy numbers converts into set of crisp numbers using linear triangular representation method (Table 4 and Fig. 4). 
Robertus Nugroho Perwiro Atmojo et al. / American Journal of Applied Sciences 11 (4): 666-680, 2014

Table 3. Questionnaire validity test

\begin{tabular}{llll}
\hline Items & Corrected Item-Total Correlation & r-0.05 (95\%). Df $=28$ & Valid? \\
\hline UC1 & 0.464 & 0.31 & Valid \\
UC2 & 0.530 & 0.31 & Valid \\
UC3 & 0.462 & 0.31 & Valid \\
UC4 & 0.525 & 0.31 & Valid \\
UC5 & 0.365 & 0.31 & Valid \\
UC6 & 0.465 & 0.31 & Valid \\
UC7 & 0.659 & 0.31 & Valid \\
SC1 & 0.322 & 0.31 & Valid \\
SC2 & 0.336 & 0.31 & Valid \\
SC3 & 0.487 & 0.31 & Valid \\
OC1 & 0.533 & 0.31 & Valid \\
Adeq1 & 0.406 & 0.31 & Valid \\
Att1 & 0.535 & 0.31 & Valid \\
Att2 & 0.645 & 0.31 & Valid \\
Att3 & 0.343 & 0.31 & Valid \\
Iso1 & 0.449 & 0.31 & Valid \\
Iso2 & 0.529 & Valid \\
Iso3 & 0.634 & 0.31 & Valid \\
Iso4 & 0.457 & 0.31 & Valid \\
Iso5 & 0.539 & 0.31 & Valid \\
\hline
\end{tabular}

Table 4. Linguistic variable for alternatives weighting and criteria weighting, adapted from Aghajani et al. (2012)

\begin{tabular}{ll}
\hline $\begin{array}{l}\text { Linguistic variable } \\
\text { for fuzzy numbers }\end{array}$ & $\begin{array}{l}\text { intervals of fuzzy numbers } \\
\text { conversion into crisp numbers }\end{array}$ \\
\hline Sangat Rendah (very low) & $\{(0.01),(0.01),(0.25)\}$ \\
Rendah (low) & $\{(0.01),(0.25),(0.50)\}$ \\
Normal (N) & $\{(0.25),(0.50),(0.75)\}$ \\
Tinggi (high) & $\{(0.50),(0.75),(1.00)\}$ \\
Sangat Tinggi (very high) & $\{(0.75),(1.00),(1.00)\}$ \\
\hline
\end{tabular}

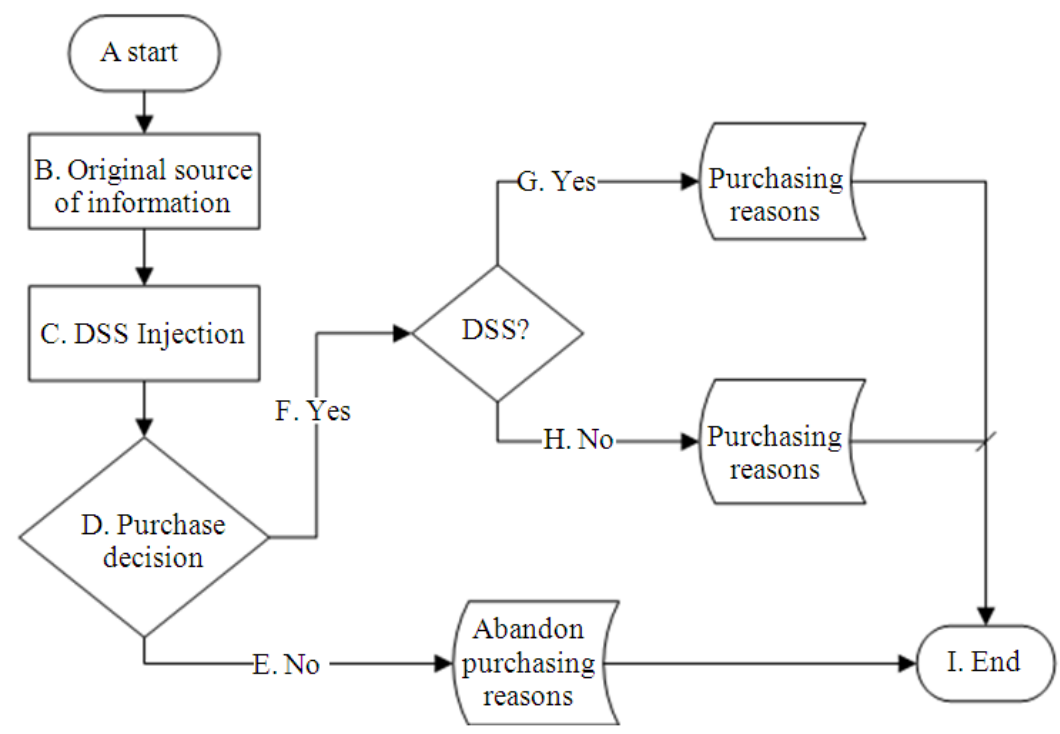

Fig. 2. Our study design 


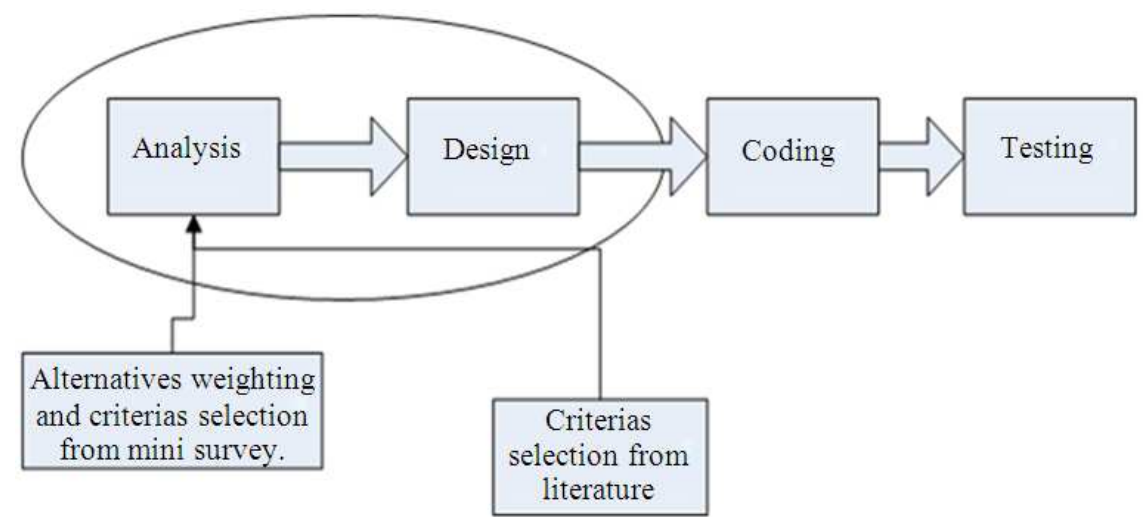

Fig. 3. Linear sequential model (Pressman, 1997)

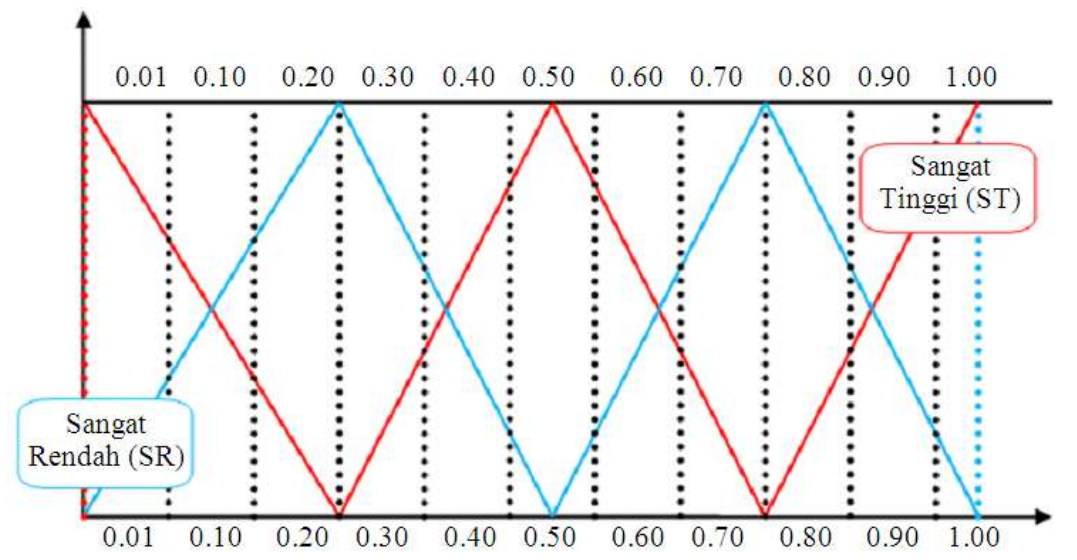

Fig. 4. The association membership of fuzzy numbers converted into crisp numbers in triangular linear representation by Kusumadewi (2003)

Table 5. The comparison matrix between alternatives towards criteria

\begin{tabular}{lllll}
\hline Criteria/Alternatives & Product price & Camera quality & Internal memory capacity & Processor speed \\
\hline BlackBerry Gemini & 0.8 & 0.5 & 0.4 & 0.60 \\
Samsung Galaxy Xcover & 0.5 & 0.6 & 0.5 & 0.70 \\
Nokia Lumia & 0.5 & 0.7 & 0.7 & 0.70 \\
Apple iPhone 5 & 0.3 & 0.9 & 0.9 & 1.00 \\
\hline
\end{tabular}

\section{Step 2:}

After getting several number of criteria and alternatives, then it could be formed comparison matrix between alternatives towards criteria. i.e., The results found from the pilot survey is about the four main criteria for selecting a smartphone, which were: (1) price, (2) the quality of the camera (mega pixels), (3) internal memory capacity and (4) the speed of the processor and the value obtained from the benchmarking review results of alternative weighting smartphone (i.e., as a weighting reference the criterion was taken from GSMarena.com smartphone review (2013)-scale 0:01 to 1:00, is as follows (Table 5).

Then the comparison matrix of alternatives towards the criteria could be filled as M1:

$$
\mathrm{M}=\left[\begin{array}{cccc}
0.8 & 0.5 & 0.4 & 0.6 \\
0.5 & 0.6 & 0.5 & 0.7 \\
0.5 & 0.7 & 0.7 & 0.7 \\
0.3 & 0.9 & 0.9 & 1.00
\end{array}\right]
$$


After the comparison of alternatives towards criteria Matrix (M1) obtained the value suitability, the next step is the consumer turn to do the weighting process. The scale used in this process is still using the fuzzy linguistic variable numbers which are converted into crisp numbers in the interval scale from 0.01 to 1.00 . The reason for using the smallest scale to the value of 0.01 is to prevent division by zero (division by the number 0 ) which can lead to the miscalculations, i.e. the consumer wants a smartphone which has the criteria shown in Table 6.

Then the weighted criteria of matrix (N1) is:

$$
\mathrm{N} 1=\left[\begin{array}{l}
0.31 \\
0.19 \\
0.19 \\
0.31
\end{array}\right]
$$

\section{Step 3:}

Do the normalized calculations for matrix M1. Use the following rules.

For the "cheaper is better" or negative criterion use the Theorem 1.

\section{Theorem 1:}

$$
n_{\mathrm{ij}}=\frac{r_{\mathrm{j}}^{\text {MIN }}}{r_{\mathrm{ij}}}
$$

Normalisation formula for negative criterion.

Then, for "bigger/faster" criterion use the Theorem 2.

\section{Theorem 2:}

$$
\mathrm{n}_{\mathrm{ij}}=\frac{\mathrm{r}_{\mathrm{ij}}}{\mathrm{r}_{\mathrm{j}}^{\mathrm{MAX}}}
$$

Normalisation formula for positive criterion.

Then, the result obtained should be:

Row $1.1($ Product price $)=\frac{\operatorname{Min}(0.8 ; 0.5 ; 0.5 ; 0.3)}{0.8}=\frac{0.3}{0.8}=0.375$

Row $1.2($ Camera quality $)=\frac{0.5}{\operatorname{Max}(0.5 ; 0.6 ; 0.7 ; 0.9)}=\frac{0.5}{0.9}=0.55$

$$
\begin{aligned}
& \text { Row } 1.3 \text { (Internal memory capacity) = } \\
& \frac{0.4}{\operatorname{Max}(0.4 ; 0.5 ; 0.7 ; 0.9)}=\frac{0.4}{0.9}=0.44
\end{aligned}
$$

$$
\begin{aligned}
& \text { Row } 1.4 \quad \text { (Processor } \quad \text { speed) } \\
& \frac{0.6}{\operatorname{Max}(0.6 ; 0.7 ; 0.7 ; 1.00)}=\frac{0.6}{1.00}=0.60
\end{aligned}
$$$$
\text { Row } 2.1 \text { (Product price) }=\frac{\operatorname{Min}(0.3 ; 0.5 ; 0.5 ; 0.8)}{0.5}=\frac{0.3}{0.5}=0.60
$$$$
\text { Row } 2.2 \text { (Camera quality) }=\frac{0.6}{\operatorname{Max}(0.5 ; 0.6 ; 0.7 ; 0.9)}=\frac{0.6}{0.9}=0.66
$$

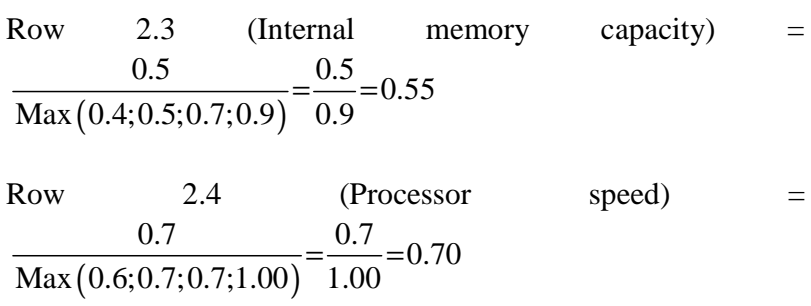$$
\text { Row } 3.1(\text { Product price })=\frac{\operatorname{Min}(0.3 ; 0.7 ; 0.7 ; 0.8)}{0.5}=\frac{0.3}{0.5}=0.60
$$$$
\text { Row } 3.2 \text { (Camera quality) }=\frac{0.7}{\operatorname{Max}(0.5 ; 0.6 ; 0.7 ; 0.9)}=\frac{0.7}{0.9}=0.77
$$

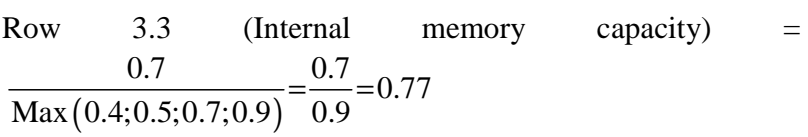

Row $\frac{3.4}{0.7}=\frac{0.7}{\operatorname{Max}(0.6 ; 0.7 ; 0.7 ; 1.00)}=0.70$
1.00

Row $4.1($ Product price $)=\frac{\operatorname{Min}(0.3 ; 0.5 ; 0.5 ; 0.8)}{0.3}=\frac{0.3}{0.3}=1.00$

Row 4.2 (Camera quality) $=\frac{0.9}{\operatorname{Max}(0.5 ; 0.6 ; 0.7 ; 0.9)}=\frac{0.9}{0.9}=1.00$

$$
\begin{aligned}
& \text { Row } 4.3 \text { (Internal memory capacity) = } \\
& \frac{0.9}{\operatorname{Max}(0.4 ; 0.5 ; 0.7 ; 0.9)}=\frac{0.9}{0.9}=1.00
\end{aligned}
$$

$$
\begin{array}{lll}
\text { Row } & \begin{array}{l}
4.4 \\
\frac{1.00}{\operatorname{Max}(0.6 ; 0.7 ; 0.7 ; 1.00)}
\end{array}=\frac{1.00}{1.00}=1.00
\end{array}
$$

Then, the results for the normalized M1 could be filled as $\mathrm{MN}$ : 


$$
\mathrm{MN}=\left[\begin{array}{cccc}
0.375 & 0.55 & 0.44 & 0.60 \\
0.60 & 0.66 & 0.55 & 0.70 \\
0.60 & 0.77 & 0.77 & 0.70 \\
1.00 & 1.00 & 1.00 & 1.00
\end{array}\right]
$$

\section{Step 4:}

The final step is implementing the SAW algorithm, the algorithm can be seen in Theorem 3 .

$$
\mathrm{A}_{\mathrm{i}}=\sum \mathrm{N} 1, \mathrm{MN}
$$

\section{Theorem 3:}

The SAW algorithm:

$$
\begin{aligned}
& \mathrm{N} 1=\left[\begin{array}{ccc}
\mathrm{x} 1 & \cdots & (\mathrm{x} 1, \mathrm{n}) \\
\vdots & \ddots & \vdots \\
(\mathrm{x} 3,1) & \cdots & (\mathrm{x} 3, \mathrm{n})
\end{array}\right] ; \mathrm{MN}=\left[\begin{array}{ccc}
\mathrm{y} 1 & \cdots & (\mathrm{y} 1, \mathrm{n}) \\
\vdots & \ddots & \vdots \\
(\mathrm{y} 3,1) & \cdots & (\mathrm{y} 3, \mathrm{n})
\end{array}\right] \\
& \mathrm{N} 1 \mathrm{MN}= {\left[\begin{array}{ccc}
\mathrm{x} 1 \mathrm{y} 1 & +\cdots+ & (\mathrm{x} 1, \mathrm{n})(\mathrm{y} 3,1) \\
\vdots & \ddots & \vdots \\
(\mathrm{x} 3,1) \mathrm{y} 1 & +\cdots+ & (\mathrm{x} 3, \mathrm{n})(\mathrm{y} 3, \mathrm{n})
\end{array}\right] }
\end{aligned}
$$

$$
\begin{aligned}
\mathrm{A}_{1}= & (0.31 \times 0.375)+(0.19 \times 0.55)+(0.19 \times 0.44)+ \\
& (0.31 \times 0.60)\}=0.490 \\
\mathrm{~A}_{2}= & \{(0.31 \times 0.6)+(0.19 \times 0.66)+(0.19 \times 0.55)+(0.31 \times \\
& 0.70)\}=0.633 \\
\mathrm{~A}_{3}= & \{(0.31 \times 0.6)+(0.19 \times 0.77)+(0.19 \times 0.77)+ \\
& (0.31 \times 0.70)\}=0.695 \\
\mathrm{~A}_{4}= & \{(0.31 \times 1.00)+(0.19 \times 1.00)+(0.19 \times 1.00)+ \\
& (0.31 \times 1.00)\}=1.00
\end{aligned}
$$

Then, the final calculation results using Fuzzy SAW method can be seen in Table 7 .
The 2nd phase of Analysis steps in this study is discussing about the aspects of smartphone criteria weighting. There were many aspects can be used as the criteria weighting measurement in smartphone selection case. Aspects such as innovative features, product image, product price, recommendation among consumers, durability and portability products (Mokhlis and Yaakop, 2012); influence of advertising and after sales service (Mokhlis, 2012) and features (product quality aspects) (Pranastiti, 2012). The criterion for the smartphone selection aspects is a combination from the review on literature and the experienced smartphone user perspectives.

Results gathered from direct and close interviews of ten experienced smartphone users can be qualitatively concluded, that the aspects need to be made as the basis of smartphones criteria weighting are an innovative feature (new technology), product price, battery life and camera quality. There is no restriction relating to the number of samples use in a qualitative survey interview (Creswell, 2009; Fidel, 2008), then the professional opinion of ten respondents can be used for criteria weighting references. Based on the literature point of view, weighting criteria aspects such as: Smartphones display/resolution, weight, dimension, processor speed, built-in memory and built-in storage were adapted from previous researches done by (Mokhlis and Yaakop, 2012; Mokhlis, 2012) and the comparison of smartphone hardware specs adapted from GSMA 2013 and HWM Singapore magazine (Wong, 2013). Visual Studio 2012 Professional edition with the Visual Basic .NET programming language is used as a designer and apps.coding tool. The final design of DSS apps Fig. 5.

Table 6. Matrix with the weighted criteria

\begin{tabular}{lr}
\hline Criteria & Weight \\
\hline Product price (-) & 0.31 \\
Camera quality (+) & 0.19 \\
Internal memory capacity (+) & 0.19 \\
Processor speed (+) & 0.31 \\
\hline
\end{tabular}

*Note: Negative $(-)=$ cheaper is better; Positive $(+)=$ bigger or faster is better

Table 7. Smartphone alternatives ranking

\begin{tabular}{lll}
\hline $\mathrm{A}_{1}$ & Ranking & Alternative recommendations \\
\hline $\mathrm{A}_{4}$ & $1(1.00)$ & Apple iPhone 5 \\
$\mathrm{A}_{3}$ & $2(0.695)$ & Nokia Lumia \\
$\mathrm{A}_{2}$ & $3(0.633)$ & Samsung Galaxy Xcover \\
$\mathrm{A}_{1}$ & $4(0.490)$ & BlackBerry Gemini \\
\hline
\end{tabular}




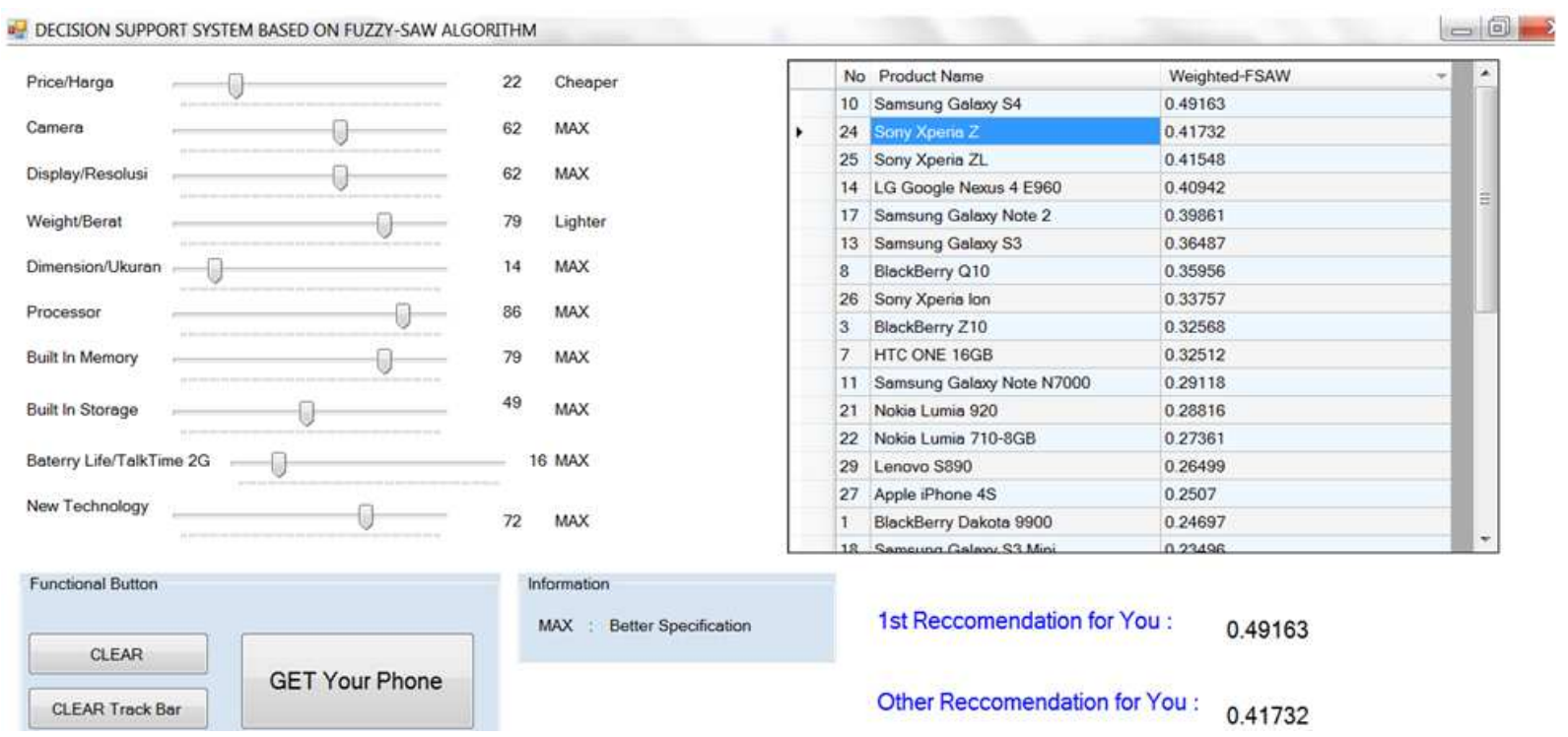

Fig. 5. The design of DSS application user interface

\section{RESULTS}

The sample used in this study consisted of 136 respondents. The data retrieval process started from May 21st, 2013 until June 27th, 2013. The majority of respondents was dominated by respondents with female gender $(52.8 \%)$ and respondents with age intervals of 25-34 years old (49.2\%) (Table 8). Because the distribution of sample population was too widespread making it difficult to do pre-test and post-test, the sample used was not representative of the entire population in Jakarta or Indonesia.

Data processing and deduction techniques that used a non-representative sample and non-probabilistic sample (purposive/accidental sampling) in this studies, refer to the studies of consumer confusion that had previously been done by (Turnbull et al., 2000; Leek and Kun, 2006; Leek and Chansawatkit, 2006).

\subsection{Aspects Causing the Consumer Confusion}

In the previous study on consumer confusion problem, the main cause of consumer confusion is closely related to consumer perceptions of unclarity confusion, similarity confusion and overchoice confusion (Mitchell and Papavasilliou, 1997; 1999; Mitchell et al., 2005; Leek and Chansawatkit, 2006; Leek and Kun, 2006). In this study the mapping technique on consumer confusion problems refers to Leek and Kun (2006).
Where through the process of direct interviews and questionnaires filling obtained the results as in Table 9-11.

A total of $75.7 \%(25.7 \%$ (SA) $+50 \%$ (A) from 136 respondents was feeling confused about which technology terms often included in sales package. Gorilla glass, AMOLED, Quad-Core, Near Field Communication (NFC), HTML 5, voice command, voice memo were some examples of technological jargon that is often ignored by the consumer. So it can be concluded that is a lot of smartphone features that is not utilized to the optimum by the consumer $($ Mean $=3.87$, stdev $=$ 0.99).

When the consumer must selecting the choice of smartphone products to be purchased. A total of $86 \%$ (23.5\% [SA] $62.5 \%+[\mathrm{A}])$ of the 136 respondents (potential buyer/buyer) facing several confusion to choose, they often asking what is the most suitable brand for them? Consumers assume that every smartphone has own its image (brand image), $($ mean $=3.98$, stdev $=$ 0.86). Consumers often stuck in a situation like choosing a smartphone based on its reputation or choosing a smartphone based on its features, the technology offered, or choosing what is the most important criteria of the smartphone they really needs. Consumer personal experience in using a specific brand of smartphone in the past and the social factors such as the suggestion from close relatives causing consumers tend to make choices of purchase products based on brand image (narrowing down the set of alternatives). 
Table 8. The data demographics of respondents

\begin{tabular}{llll}
\hline & Gender & & \\
Age (Years) & $-\mathrm{c}$ & & \\
\hline $15-24$ & Male & Female & Total \\
$25-34$ & $11(8 \%)$ & $26(19.1 \%)$ & $37(27.1 \%)$ \\
$35-44$ & $29(21.3 \%)$ & $38(27.9 \%)$ & $67(49.2 \%)$ \\
$45+$ & $17(12.5 \%)$ & $5(3.6 \%)$ & $22(16.1 \%)$ \\
Total & $7(5.1 \%)$ & $3(2.2 \%)$ & $10(7,3 \%)$ \\
& $64(46.9 \%)$ & $72(52.8 \%)$ & $136(100 \%)$ \\
\hline
\end{tabular}

Table 9. Respondents perception towards unclarity confusion adapted from (Leek and Kun, 2006) $(\mathrm{n}=136)$

\begin{tabular}{|c|c|c|c|c|c|c|}
\hline & Mean & SA $(\%)$ & $\mathrm{A}(\%)$ & $\mathrm{N}(\%)$ & $\mathrm{D}(\%)$ & $\mathrm{SD}(\%)$ \\
\hline \multicolumn{7}{|l|}{ Unclarity Confusion (UC) } \\
\hline (UC.1) Too difficult to understand & Mean $=3.13$ & 13.9 & 40.4 & 5.8 & 24.2 & 15.4 \\
\hline $\begin{array}{l}\text { all smartphone technologies, } \\
\text { because they were very complex. }\end{array}$ & Stdev $=1.34$ & $\mathrm{n}=19$ & $\mathrm{n}=55$ & $\mathrm{n}=8$ & $\mathrm{n}=33$ & $\mathrm{n}=21$ \\
\hline (UC.2) I was not able to follow the & Mean $=3.37$ & 8.8 & 50.0 & 14.7 & 22.7 & whole \\
\hline $\begin{array}{l}\text { smartphone technologies updates, } \\
\text { because its development is too fast }\end{array}$ & Stdev $=1.04$ & $\mathrm{n}=12$ & $\mathrm{n}=68$ & $\mathrm{n}=20$ & $\mathrm{n}=31$ & $\mathrm{n}=5$ \\
\hline (UC.3) Because there was a lot of & Mean $=3.36$ & 17.6 & 36.7 & 18.3 & 18.3 & 8.8 \\
\hline $\begin{array}{l}\text { smartphone features, } i \text { often forget } \\
\text { what is the most necessary smartphone } \\
\text { functions for me }\end{array}$ & Stdev $=1.22$ & $\mathrm{n}=24$ & $\mathrm{n}=50$ & $\mathrm{n}=25$ & $\mathrm{n}=25$ & $\mathrm{n}=12$ \\
\hline (UC.4) Absolutely, i prefer hardware & Mean $=3.07$ & 11.7 & 24.2 & 25.0 & 37.5 & 1.4 \\
\hline specification than software specification & Stdev $=1.07$ & $\mathrm{n}=16$ & $\mathrm{n}=33$ & $\mathrm{n}=34$ & $\mathrm{n}=51$ & $\mathrm{n}=2$ \\
\hline (UC.5) I think choosing the hardware & Mean $=2.94$ & & 33.8 & 14.7 & 30.8 & 12.5 \\
\hline $\begin{array}{l}\text { specification which are compatible with } \\
\text { its software is very difficult }\end{array}$ & Stdev $=1.21$ & $\mathrm{n}=11$ & $\mathrm{n}=46$ & $\mathrm{n}=20$ & $\mathrm{n}=42$ & $\mathrm{n}=17$ \\
\hline (UC.6) I am afraid i cannot optimized all & Mean $=3.02$ & 13.9 & 31.6 & 13.2 & 25.7 & 15.4 \\
\hline $\begin{array}{l}\text { smartphone features because they were very } \\
\text { advanced and take much time to learn it all }\end{array}$ & Stdev $=1.32$ & $\mathrm{n}=19$ & $\mathrm{n}=43$ & $\mathrm{n}=18$ & $\mathrm{n}=35$ & $\mathrm{n}=21$ \\
\hline (UC.7) There were too many & Mean $=3.87$ & 25.7 & 50.0 & 13.9 & 6.67 & 3.6 \\
\hline $\begin{array}{l}\text { technological jargons in smartphone products. } \\
\text { Those jargons makes me confused }\end{array}$ & Stdev $=0.99$ & $\mathrm{n}=35$ & $\mathrm{n}=68$ & $\mathrm{n}=19$ & $\mathrm{n}=9$ & $\mathrm{n}=5$ \\
\hline
\end{tabular}

Note: 5 = strongly agree $(\mathrm{SA}), 1$ = strongly disagree $(\mathrm{SD}), 3$ = Neither $(\mathrm{N})$

Table 10. Respondents perception towards similarity confusion adapted from (Leek and Kun, 2006) $(\mathrm{n}=136)$

\begin{tabular}{|c|c|c|c|c|c|c|}
\hline & Mean & SA $(\%)$ & $\mathrm{A}(\%)$ & $\mathrm{N}(\%)$ & $\mathrm{D}(\%)$ & $\mathrm{SD}(\%)$ \\
\hline \multicolumn{7}{|l|}{ Similarity Confusion (SC) } \\
\hline [SC.1] I do not really care about & Mean $=2.69$ & 5.8 & 32.3 & 5.8 & 37.5 & 18.3 \\
\hline the smartphone brand differences & Stdev $=1.26$ & $\mathrm{n}=8$ & $\mathrm{n}=44$ & $\mathrm{n}=8$ & $\mathrm{n}=51$ & $\mathrm{n}=25$ \\
\hline [SC.2] There were no significant & Mean $=2.30$ & 4.4 & 15.4 & & 51.4 & 21.3 \\
\hline $\begin{array}{l}\text { technological differences between } \\
\text { smartphone products }\end{array}$ & Stdev $=1.10$ & $\mathrm{n}=6$ & $\mathrm{n}=21$ & $\mathrm{n}=10$ & $\mathrm{n}=70$ & $\mathrm{n}=29$ \\
\hline [SC.3] There were no doubts, & Mean $=3.98$ & 23.5 & 62.5 & 4.4 & 8.0 & 1.47 \\
\hline $\begin{array}{l}\text { that every smartphone product } \\
\text { has own its image }\end{array}$ & Stdev $=0.86$ & $\mathrm{n}=32$ & $\mathrm{n}=85$ & $\mathrm{n}=6$ & $\mathrm{n}=11$ & $\mathrm{n}=2$ \\
\hline
\end{tabular}

Note: 5 = strongly agree $(\mathrm{SA}), 1$ = strongly disagree $(\mathrm{SD}), 3=$ Neither $(\mathrm{N})$

Table 11. Respondents perception towards overchoice confusion adapted from (Leek and Kun, 2006) (n=136)

\begin{tabular}{|c|c|c|c|c|c|c|}
\hline & Mean & SA (\%) & $\mathrm{A}(\%)$ & $\mathrm{N}(\%)$ & $\mathrm{D}(\%)$ & $\mathrm{SD}(\%)$ \\
\hline $\begin{array}{l}\text { Overchoice Confusion (OC) } \\
\text { [OC.1] Every smartphone vendors. } \\
\text { launching too many brands, services, } \\
\text { and models of its products to the market. } \\
\text { These situations makes me confused. }\end{array}$ & $\begin{array}{l}\text { Mean }=3.89 \\
\text { Stdev }=0.82\end{array}$ & $\begin{array}{l}17.6 \\
n=24\end{array}$ & $\begin{array}{l}65.4 \\
\mathrm{n}=89\end{array}$ & $\begin{array}{l}6.6 \\
n=9\end{array}$ & $\begin{array}{l}9.5 \\
n=13\end{array}$ & $\begin{array}{l}0.7 \\
\mathrm{n}=1\end{array}$ \\
\hline
\end{tabular}

Note: 5 = strongly agree $(\mathrm{SA}), 1=$ strongly disagree $(\mathrm{SD}), 3=$ Neither $(\mathrm{N})$ 
A large number of product vendors that offer the latest smartphone: The features, the services, the advanced technology and the very competitive products pricing makes the overchoice confusion as a second number have most confusing aspects for consumers. A total of $83 \%$ $(17.6 \%$ [SA] $65.4 \%+[\mathrm{A}])$ of 136 respondents had hesitated when confronted to a lot of product choices. in example: Choose the current brand new edition of smartphone product that has a several number of advanced features or choosing a smartphone product that already have a reliable reputation and has a luxurious image $($ Mean $=3.89$, stdev $=$ 0.82 ). Overchoice confusion problems in this study can be analogous like consumers who want to choose between the Samsung Galaxy S4 product that comes with a lot of high tech features and with the latest technology that is very interesting or the Apple Iphone 5 product that has the reliability, durability, perfect constituent material and a luxurious image and technology jargon is the third most confusing aspects for the consumers.

\subsection{Consumer Strategies Towards Information Searching}

At the time of going to buy a smartphone, as much as $96.2 \%(30.8 \%$ [SA] $+65.4 \%$ [A]) of the 136 respondents would to spend time to seek additional information about the products to be purchased $($ Mean $=4.24$, stdev $=0.61$ ). The process of information search about the smartphone technical specs was usually done by the consumer by doing several actions such as browsing the internet, searching for the results of product reviews on forums or social networking. Nevertheless at the time of D-day purchases, the consumer purchase preference may change. Table 12 shows data on consumer attitudes in preparation for the purchase of a smartphone product.

\subsection{Consumer Perceptions Towards the Availability of Source of Information}

A total of $94.8 \%(29.4 \%(\mathrm{SA})+65.4 \%$ (A) of the 136 respondents are expecting for always get product knowledge from vendors. The vendor that educate consumers so that they can distinguish about genuine or fake products or give several techniques that may made consumers reach the optimal utilization of product features, is the most expected vendor that the consumers want to deal with. These findings are in accordance to the theory of Eriksson and Sharma (2007) that in order to gain consumer loyalty (repetitive buying), the skills required for every seller (vendor) is the ability to educate their customers on a regular basis. Shown in Table 13, the results of consumer perceptions towards the availability of source of information's.

\subsection{The Main Source of Information Used by the Consumer as a Purchase Reference}

In Table 14 it can be observed that $45.58 \%$ of respondents relied on Word of Mouth communication as product purchase reference. The majority of respondents considered that the suggestion from close relatives is highly reliable and trustworthy. A total of $16.17 \%$ of respondents considered the advice and the guidance from the salespeople as a reliably product purchase reference, because respondents thought that the key competitive from each dealers are its expertise and its honesty (trustworthiness) (Liu and Leach, 2001).

\section{DISCUSSION}

Results from 136 respondents as research samples are, there was conversion from 136 potential buyers into 27 smartphone buyers. Referring to the study design in Fig. 2 as much as sixteen (16) buyers choose Word of Mouth information as the purchasing reference and two (2) purchases spearheaded by the recommendation of a DSS application. Buying test results showed there was only 27 transactions occurred from 136 potential buyers in the period of May 21, 2013 until June 27, 2013 it happens because some of respondents is simply do price comparisons amongst smartphone reseller.

Table 12. Consumer strategies to search for additional product information adapted from (Leek and Kun, 2006). $(\mathrm{n}=136)$

\begin{tabular}{|c|c|c|c|c|c|c|}
\hline & Mean & $\mathrm{SA}(\%)$ & $\mathrm{A}(\%)$ & $\mathrm{N}(\%)$ & $\mathrm{D}(\%)$ & $\mathrm{SD}(\%)$ \\
\hline [Att.1] I will not doing too much effort & Mean $=2.50$ & 6.6 & 25.7 & 2.9 & 41.1 & 23.5 \\
\hline $\begin{array}{l}\text { just to search for additional information } \\
\text { about smartphone products }\end{array}$ & Stdev $=1.28$ & $\mathrm{n}=9$ & $\mathrm{n}=35$ & $\mathrm{n}=4$ & $\mathrm{n}=56$ & $\mathrm{n}=32$ \\
\hline [Att.2] For me, it is very important to & Mean $=4.09$ & 29.4 & 58.0 & 6.6 & 4.4 & 1.4 \\
\hline $\begin{array}{l}\text { consider all the alternatives before i buy } \\
\text { a smartphone product }\end{array}$ & Stdev $=0.81$ & $\mathrm{n}=40$ & $\mathrm{n}=79$ & $\mathrm{n}=9$ & $\mathrm{n}=6$ & $\mathrm{n}=2$ \\
\hline [Att.3] because i am afraid buying a wrong & Mean $=4.24$ & 30.8 & 65.4 & 0.7 & 2.9 & 0.0 \\
\hline $\begin{array}{l}\text { product, i prefer do several research like } \\
\text { searching for additional information about }\end{array}$ & Stdev $=0.61$ & $\mathrm{n}=42$ & $\mathrm{n}=89$ & $\mathrm{n}=1$ & $\mathrm{n}=4$ & $\mathrm{n}=0$ \\
\hline
\end{tabular}

Note: 5 = strongly agree $(\mathrm{SA}), 1=$ strongly disagree $(\mathrm{SD}), 3=$ Neither $(\mathrm{N})$ 
Robertus Nugroho Perwiro Atmojo et al. / American Journal of Applied Sciences 11 (4): 666-680, 2014

Table 13. Consumer perceptions towards the availability of source of information adapted from (Leek and Kun, 2006) $(\mathrm{n}=136)$

\begin{tabular}{|c|c|c|c|c|c|c|}
\hline & Mean & $\mathrm{SA}(\%)$ & $\mathrm{A}(\%)$ & $\mathrm{N}(\%)$ & D0020 (\%) & SD \\
\hline $\begin{array}{l}\text { (Iso.1) I think i enjoy almost every } \\
\text { smartphone products advertisement } \\
\text { in each media. Those advertisement } \\
\text { makes me knowing about new products } \\
\text { are available in market }\end{array}$ & $\begin{array}{l}\text { Mean }=4.08 \\
\text { Stdev }=0.61\end{array}$ & $\begin{array}{l}18.3 \\
\mathrm{n}=25\end{array}$ & $\begin{array}{l}76.4 \\
n=104\end{array}$ & $\begin{array}{l}1.4 \\
\mathrm{n}=2\end{array}$ & $\begin{array}{l}2.9 \\
\mathrm{n}=4\end{array}$ & $\begin{array}{l}0.7 \\
\mathrm{n}=1\end{array}$ \\
\hline $\begin{array}{l}\text { [Iso.2] I think mostly smartphone } \\
\text { advertisements are trustworthy and } \\
\text { can be expected }\end{array}$ & $\begin{array}{l}\text { Mean }=3.80 \\
\text { Stdev }=0.86\end{array}$ & $\begin{array}{l}19.1 \\
\mathrm{n}=26\end{array}$ & $\begin{array}{l}52.2 \\
\mathrm{n}=71\end{array}$ & $\begin{array}{l}18.3 \\
\mathrm{n}=25\end{array}$ & $\begin{array}{l}10.2 \\
\mathrm{n}=14\end{array}$ & $\begin{array}{l}0.0 \\
\mathrm{n}=0\end{array}$ \\
\hline $\begin{array}{l}\text { [Iso.3] The recommendation and } \\
\text { the suggestion from sales team are } \\
\text { almost always helps me in buying a } \\
\text { smartphone product }\end{array}$ & $\begin{array}{l}\text { Mean }=3.75 \\
\text { Stdev }=0.75\end{array}$ & $\begin{array}{l}5.8 \\
\mathrm{n}=8\end{array}$ & $\begin{array}{l}76.4 \\
n=104\end{array}$ & $\begin{array}{l}5.8 \\
\mathrm{n}=8\end{array}$ & $\begin{array}{l}11 \\
\mathrm{n}=15\end{array}$ & $\begin{array}{l}0.7 \\
\mathrm{n}=1\end{array}$ \\
\hline $\begin{array}{l}\text { [Iso.4] Too much information in the } \\
\text { smartphone promos content, makes } \\
\text { it more difficult to understood }\end{array}$ & $\begin{array}{l}\text { Mean }=3.74 \\
\text { Stdev }=0.82\end{array}$ & $\begin{array}{l}8.8 \\
\mathrm{n}=12\end{array}$ & $\begin{array}{l}72 \\
\mathrm{n}=98\end{array}$ & $\begin{array}{l}3.6 \\
\mathrm{n}=5\end{array}$ & $\begin{array}{l}15.4 \\
\mathrm{n}=21\end{array}$ & $\begin{array}{l}0.0 \\
\mathrm{n}=0\end{array}$ \\
\hline $\begin{array}{l}\text { [Iso.5] Every smartphone vendors } \\
\text { need to provide facilities for consumers } \\
\text { to gain the knowledge or valuable } \\
\text { information about their products }\end{array}$ & $\begin{array}{l}\text { Mean }=4.00 \\
\text { Stdev }=0.58\end{array}$ & $\begin{array}{l}17.6 \\
n=24\end{array}$ & $\begin{array}{l}65.4 \\
\mathrm{n}=89\end{array}$ & $\begin{array}{l}16.9 \\
\mathrm{n}=23\end{array}$ & $\begin{array}{l}0.0 \\
\mathrm{n}=0\end{array}$ & $\begin{array}{l}0.0 \\
\mathrm{n}=0\end{array}$ \\
\hline $\begin{array}{l}\text { [Iso.6] I think the vendors are trying } \\
\text { to educate its consumer for the product } \\
\text { knowledge, seems more } \\
\text { "bonafide" than those not }\end{array}$ & $\begin{array}{l}\text { Mean }=4.24 \\
\text { Stdev }=0.53\end{array}$ & $\begin{array}{l}29.4 \\
\mathrm{n}=40\end{array}$ & $\begin{array}{l}65.4 \\
\mathrm{n}=89\end{array}$ & $\begin{array}{l}5.1 \\
\mathrm{n}=7\end{array}$ & $\begin{array}{l}0.0 \\
\mathrm{n}=0\end{array}$ & $\begin{array}{l}0.0 \\
\mathrm{n}=0\end{array}$ \\
\hline
\end{tabular}

Note: 5 = strongly agree $(\mathrm{SA}), 1$ = strongly disagree $(\mathrm{SD}), 3$ = Neither $(\mathrm{N})$

Table 14. The main source of information often used by the consumer as a purchase reference

\begin{tabular}{lll}
\hline Source of information & Percentage & Frequency \\
\hline 1. Word of Mouth & 45.58 & $\mathrm{n}=62$ \\
2. Product review from several experienced users & 12.50 & $\mathrm{n}=17$ \\
3. Product advertisement & 10.30 & $\mathrm{~N}=14$ \\
4. The guidance from the internet & 11.00 & $\mathrm{n}=15$ \\
5. The guidance from the salespeople & 16.17 & $\mathrm{n}=22$ \\
6. Other (DSS, club members) & 4.410 & $\mathrm{n}=6$ \\
\hline
\end{tabular}

Or, some of the respondents just visited the shopping center ITC Fatmawati (not/do not have the intention to purchase a smartphone). The main source of consumer confusion is found to originate from the similarity confusion, specifically the problems derived from the brand image.

\section{CONCLUSION}

Results of this study indicate that the Fuzzy SAWbased DSS application has potential ability as an another alternatives of conventional CRS to reducing consumer confusion. Despite the recommendations generated by DSS application have not been entirely accurate and efficient. Two transactions occurred because of the recommendation from DSS application are still confirmable by the type of value-oriented consumer. The confirming way they did was to re-discuss the results obtained from DSS with the salespeople. After getting the explained confirmation and objective recommendation from salespeople towards the outcomes of DSS, then the consumer did the purchasing. In this case, DSS apps serves as a useful tool to narrow down the set of product alternatives based on the criteria set by the consumers. Furthermore the final result in the form of purchase decisions by consumers are still need advice and suggestion from other parties (share/delegate) (Leek and Chansawatkit, 2006; Leek and Kun, 2006; Mitchell and Papavasilliou, 1997). This finding is in accordance with the facts found by Elmorshidy (2013), where consumers can feel more confident to make a purchase when they have been getting advice and suggestion from the other party (e.g., advice and suggestion from the salespeople).

\subsection{Limitation}

In this report the correlations between constructs causing consumer confusion such as: Unclarity confusion, similarity confusion and overchoice confusion are not discussed in depth, even though the research was done by real buying test. Too difficult to do test with the control group and the experimental group in the wide spread samples. Therefore used purposive sampling (accidental 
sampling) as a sampling technique, as in previous studies on consumer confusion was done by (Turnbull et al., 2000; Leek and Chansawatkit, 2006; Leek and Kun, 2006). This study using a static DSS apps without using a database management system. The philosophy of software testing like $\alpha-\beta$ testing as in rules by (Pressman, 1997) was not conducted in this study. Because there is no provision which provides that each prototype application is required to apply the philosophy of software testing like $\alpha-\beta$ tested first before its directly tested to the research object. This refers to the experimental prototype DSS applications on previous studies by Rodrigues et al. (2011); Afshari et al. (2010); Aghajani et al. (2012); Jesus et al. (2007) and Bonometti (2011) that does not applying those rules. Analysis of the accuracy and reliability of the calculation criteria and the alternative weighting algorithm Fuzzy SAW was not done in this study. Since the focus of this research is to propose the use of DSS applications SAW Fuzzy approach as an alternative of conventional CRS.

\subsection{Recommendation for Further Studies}

In The use of DSS applications as an alternative conventional CRS has potential values. Tests using a static DSS desktop based application and research environment with the object of smartphone products has contributed to two of the 27 purchases by consumers. It could be imagined if the DSS applications built on the web based platform or on the mobile based platform. Future research on consumer confusion problems with applicating the DSS applications in the scope of products/services that are included in the primary needs of human being (food, clothing, shelter) allows to attract more consumers to use it. This conjecture is based on research conducted by Freedman et al. (2009) on the observation about pattern of visitor preferences while in the shopping centers. Where clothing and food are the most frequently purchased products by consumers during a visit to a modern shopping mall. There is an interesting case from the study of Freedman et al. (2009) in which as many as $56 \%$ of survey respondents felt quite satisfied (not too satisfied) in the post-evaluation visit to the shopping center which is the object of research. There is a possibility that this condition may be caused by the problems of consumer confusion. Then, our suggestion model Fig. 6.

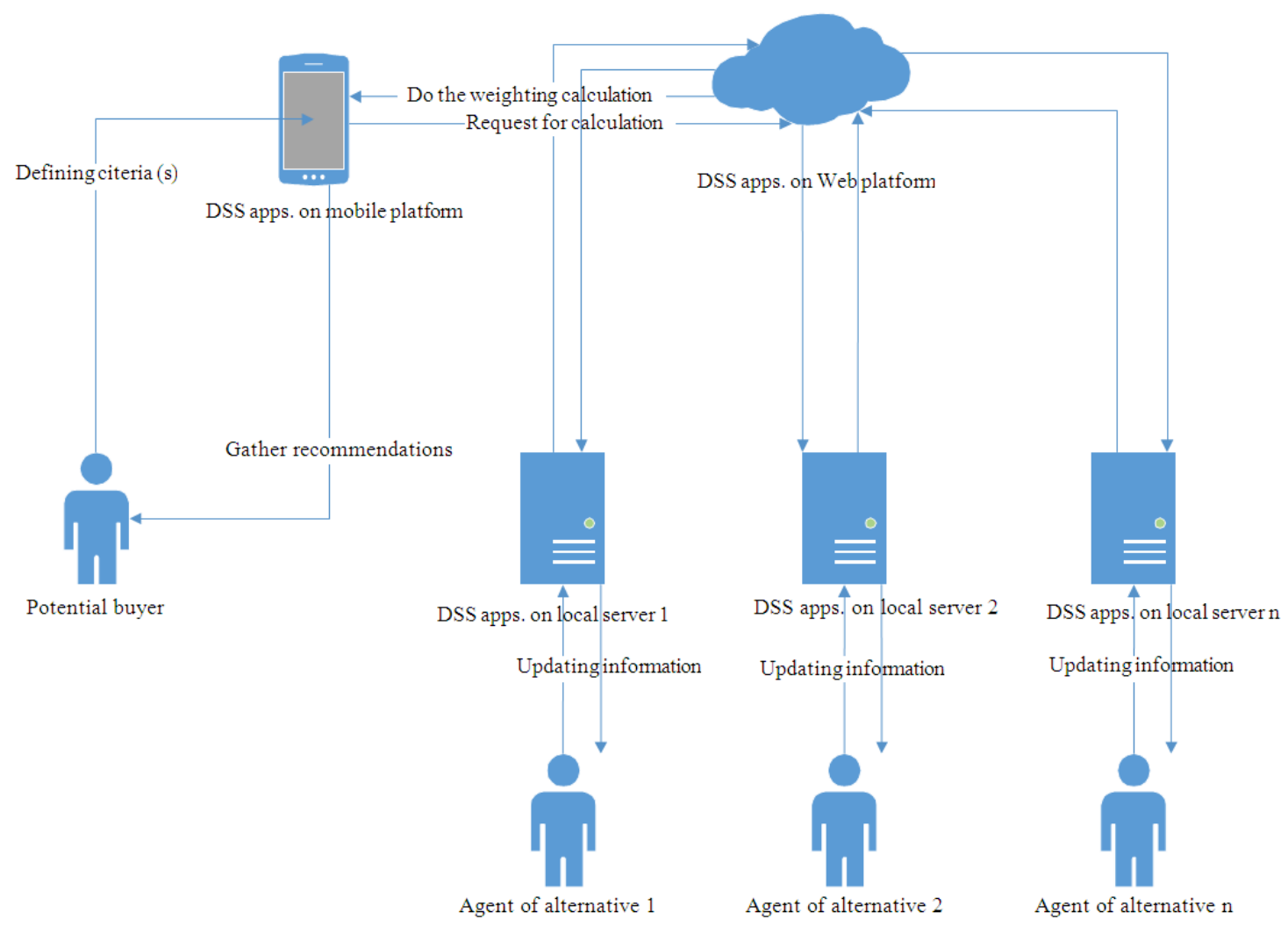

Fig. 6. Our suggestion DSS application model for further studies 
Conceptual model in Fig. 6 is our suggestion about DSS application development as another alternative of conventional CRS. In Fig. 6, modeled a combination of mobile based DSS applications in tandem with a web based DSS applications which are integrated with each other. Agent of Alternative (AoA) served as the information updater about products/services sold as well as consultants who can provide advice and recommendations in real time to consumers, as suggested by Elmorshidy (2013). AoA tasks may be vary depending on the type of industry. In example, in the restaurant industry, AoA can updates information such as the availability of a table, the food menu stock availability, price changes and so on. Or, in the car rental industry, AoA can disseminate information about the availability of cars, rental fees and rental locations. With the use of high and advanced technology features of a nowadays smartphone, consumers simply need to fingers on smartphone screen, provide criteria weighting and get the recommendation from the DSS apps in real time condition.

\section{REFERENCES}

Afshari, A., M. Mojahed and R.M. Yusuff, 2010. Simple additive weighting approach to personnel selection problem. Int. J. Innov. Manage., Technol., 1: 511515. DOI: 10.7763/IJIMT.2010.V1.89

Aghajani, H., M. Sedaghat, H. Dargahi and M. Pourhossein, 2012. Applying VIKOR, TOPSIS and SAW in fuzzy environment for ranking suppliers in supply chain: A case study. Am. J. Sci. Res., 48: 1019.

Bonometti, R.J., 2011. Spreadsheet-based decision support system/expert system shell for student projects. Int. J. Educ. Res., 6: 91-108.

Case, C.J. and D.L. King, 2008. Phishing for undergraduate students. Res. Higher Educ. J., 100106.

Casini, L., A. Cavicchi and A.M. Corsi, 2008. Trends in the british wine market and consumer confusion. Br. Food J., 110: 545-558. DOI: 10.1108/00070700810877870

Creswell, J.W., 2009. Research Design: Qualitative, Quantitative and Mixed Methods Approaches. 1st Edn., SAGE Publications, Los Angeles, ISBN-10: 1412965578, pp: 260.

Elmorshidy, A., 2013. Applying the technology acceptance and service quality models to live customer support chat for e-commerce websites. J. Applied Bus. Res., 29: 589-595.
Eom, S.B., 2001. Decision Support System. 2nd Edn., International Thomson Publishing Company England, London.

Eret, E. and T. Gokmenoglu, 2010. Plagiarism in higher education: A case study with prospective academicians. Proc. Soc. Behav. Sci., 2: 3303-3307. DOI: $10.1016 /$ j.sbspro.2010.03.505

Eriksson, K. and D.D. Sharma, 2007. Buyer loyalty development through seller education of service buyers. J. Euromarket., 16: 17-31. DOI: 10.1300/J037v16n04_03

Fidel, R., 2008. Are we there yet?: Mixed methods research in library and information science. Library Inform. Sci. Res., 30: 265-272. DOI: 10.1016/j.lisr.2008.04.001

Freedman, C., M. Andrle, R. Garcia-Saltos, D. Hermawan and D. Laxton et al., 2009. Adding Indonesia to the Global Projection Model. 1st Edn., International Monetary Fund, ISBN-10: 1451918143, pp: 272.

Jesus, N.E., J.C. Rodrigues and C.H. Antunes, 2007. A multicriteria decision support system for housing evaluation. Decision Support Syst., 43: 779-790. DOI: 10.1016/j.dss.2006.03.014

Kasper, H., J. Bloemer, P.H. Driessen, 2010. coping with confusion the case of the dutch mobile phone market. Manage. Service Q., 20: 140-160. DOI: 10.1108/09604521011027570

Kusumadewi, M.S., 2003. Artificial Intellegen ce merupakan "salah satu bagian ilmu komputer yang membuat agar mesin (komputer) dapat melakukan pekerjaan seperti dan sebaik yang dilakukan oleh manusia.

Leek, S. and D. Kun, 2006. Consumer confusion in the Chinese personal computer market. J. Product Brand Manage., 15: 184-193. DOI: 10.1108/10610420610668621

Leek, S. and S. Chansawatkit, 2006. Consumer confusion in the thai mobile phone market. J. Consumer Behav., 5: 518-532. DOI: 10.1002/cb.200

Liu, A.H. and M.P. Leach, 2001. Developing loyal customers with a value-adding sales force: Examining customer satisfaction and the perceived credibility of consultative salespeople. J. Personal Selling Sales Manage., 2: 147-156. DOI: 10.1080/08853134.2001.10754265

Lugtig, P., G.J.R.L.M. Frerichs and A. Greven, 2011. Estimating nonresponse bias and mode effects in a mixed-mode survey. Int. J. Market Res., 53: 669686. DOI: 10.2501/IJMR-53-5-669-686 
Mitchell, V.W. and V. Papavasilliou, 1997. Exploring consumer confusion in the watch market. Markett. Intell. Plann., 15: 164-164. DOI: 10.1108/10610429910284300

Mitchell, V.W. and V. Papavassiliou, 1999. Marketing causes and implications of consumer confusion. J. Product. Brand Manage., 8: 319-342. DOI: 10.1108/10610429910284300

Mitchell, V.W., G. Walsh and M. Yamin, 2005. Towards a conceptual model of consumer confusion. Adv. Consumer Res., 32: 143-150.

Mokhlis, S. and A.Y. Yaakop, 2012. Consumer choice criteria in mobile phone selection: An investigation of malaysian university students. Int. Rev. Soc. Sci. Humanit., 2; 203-212.

Mokhlis, S., 2012. An empirical analysis of consumer product evaluation from an ethnic subcultural perspective. Asian Culture History, 4: 69-76. DOI: 10.5539/ach.v4n2p69

Nowduri, S., 2011. Management information system and business decision making: Review, analysis and recommendations. J. Manage. Market. Res., 7: 1-8.

Pranastiti, P.D., 2012. Hubungan antara kualitas produk dan kepuasan konsumen dengan word of mouth communication pada mahasiswa pengguna blackberry di universitas surabaya. J. Ilmiah Mahasiswa Univ. Surabaya, 1: 1-8.
Pressman, R.S., 1997. Software Engineering. 7th Edn., McGraw Hill, New York, ISBN-10: 0073375977, pp: 928.

Rodrigues, J.C., A. Simao and C.H. Antunes, 2011. A GIS based multicriteria spatial decision support system for planning urban infrastructures. Decision Support Syst., 51: 720-726.

Sarjono, H. and W. Julianita, 2011. SPSS Vs LISREL: Sebuah Pengantar, Aplikasi untuk Riset. 1st Edn., Indonesia, ISBN-10: 6028570702, pp: 282.

Schweizer, M., A.J. Kotouc T. Wagner, 2006. Scale development for consumer confusion. Adv. Consumer Res., 33: 184-190.

Setiawan, A. Hermani and S. Suryoko, 2012. Pengaruh atribut produk dan iklan terhadap keputusan pembelian sepeda motor yamaha jupiter series pada dealer yamaha agung motor semarang. J. Ilmu Admin. Bisnis, 12: 1-17.

Tavakol, M. and R. Dennick, 2011. Making sense of cronbach's alpha. Int. J. Med. Educ., 2: 53-55. DOI: 10.5116/ijme.4dfb.8dfd

Turnbull, P.W., S. Leek and G. Ying, 2000. Customer confusion: The mobile phone market. J. Market. Manage., 16: 143-163. DOI: $10.1362 / 026725700785100523$

Wong, S., 2013. Smart decisions. HWM Singapore. 